\title{
«THE UNSIMPLE» BY T. PROKHASKO: A QUASI-HISTORICAL NOVEL
}

\author{
Lubov Pecherskyh \\ Ph.D. in Philology, Doctorate Student, Leonid Ushkalov Department of Ukrainian Literature \\ and Journalism, H. S. Skovoroda Kharkiv National Pedagogical University, Ukraine \\ e-mail: lpecherskyh@i.ua, orcid.org/0000-0003-1377-446
}

\section{Summary}

A historical novel is a work that is based on a historical plot, built on the reproduction in the artistic form of a certain historical epoch, a certain period of the people's or the country's past. In view of this, in a historical novel, historical truth must be combined with artistic truth, historical facts with artistic fiction, real historical figures with fictional characters. The postmodern ideology of the multiplicity of meanings, the hesitation in determining the differences between the false and the true, justify today's increase in interest in history and the historical novel as a modern textual reflection of the past.

The study considers the artistic interpretation of the genre of quasi-historical postmodern novel on the material of the text "The UnSimple" by T. Prokhasko. The genre features of the text are determined, in particular inscribing a variant of an event to a certain historical epoch, defining national features with the help of a pseudo-historical plot, creating a geographical utopia and avoiding linearity, rooting a person in a new geographical landscape as a strategy ofhistorical discourse reconstruction.

Keywords: genre, historical discourse, quasi-historical novel, postmodernism, topos.

$$
\text { DOI: https://doi.org/10.23856/4808 }
$$

\section{Introduction}

The formation of the historical novel was marked by temporal dimensions from antiquity to the present. The Middle Ages, Renaissance, Baroque, Romanticism, Realism, and Modernism contributed to the development of the historical novel genre.

The development of the genre of historical novel directly influenced the formation of modifications and transformations of its species. Models of genre differentiations arose due to the need of artistic development of the past in various art forms, the creation of which was prompted by the expansion of the ideological and artistic range of historical themes.

The historian depends entirely on archival documents and sources, so it is not always possible to give a thorough answer to the questions posed by the challenges of time. A writer, unlike a historian, can defend his position basing not only on facts, but on creative fiction, intuitive discoveries. This is especially noticeable in the postmodern historical novel, where the documentary takes the form not of a historical fact, but of a fact of the era.

\section{Theoretical framework}

According to L. Hutcheon (Hutcheon, 1988: 122), the postmodern historical novel being in the cross point of literature and history is transformed into a kind of historiographical metaliterature, in particular into a quasi-historical novel, which has its roots in parody pseudo-historical texts of the Baroque period. 
The term "pseudo-historical" or "quasi-historical" novel was firstly defined by M. Lypovetsky (Lypovetsky, 1997), aspects of understanding history in the postmodern novel are voiced in the works by V. Kurytsyn (Kurytsyn, 2000), I. Skoropanova (Skoropanova, 2007), M. Epstein (Epshtein, 2000).

The postmodern quasi-historical novel in a less degree uses a factual narrative - a narrative as close as possible to reality, to an increasing degree - a fictional narrative - a narrative of fictional events. The problem of interaction of factual and fictional planes occupies a central place in the quasi-historical novel, the specificity of which lies in the author's transformation of real events into fictional ones. Such transformational skill of the author deprives the reader of the opportunity to independently distinguish between factual and fictional events in the work.

The poetics of postmodern quasi-historical novels is structured by neomythologisms, the logic of a nonlinear novel in the construction of their plots, compositions, focusing on the deconstruction of ideas of traditional transculturalism, common Christian roots, "fraternal" unity of Slavs, a myths about the search for a new messiah, the salvation of society by the historically significant role of woman, the privation of the exile nation.

A striking example of Ukrainian quasi-historical novelism is the work of one of the most significant figures in the modern literary process, Ivano-Frankivsk poet, writer, essayist Taras Prokhasko, whose original style influenced the work of many younger prose writers.

As R. Kharchuk points out, in the novel "The UnSimple" T. Prokhasko, for whom the place that is mastered by the genus and forms the genus is of special importance, recombines the plot of tribal history, traditional for European literature, which reflects the history of the people. T. Prokhasko appeals to the strategy of identifying tribal histories with the history of ethnographic territory (Kharchuk, 2011: 171).

T. Gundorova (Hundorova, 2005: 102) talks about the mythologizing of the Western European myth of Galicia in the author's novel. I. Bondar-Tereshchenko sees metaphysical local lore in the novel, expressed within the historical narrative (Bondar-Tereshchenko, 2003: 58).

The writer names the authors to whom the threads of his characters, plot and stylistic lead. These are M. Mamardashvili (phenomenon of consciousness), G. G. Marquez, K. Ransmayr, J. Le Goff, H. L. Borges, S. Dovlatov, B. Grabal, D. Kish, the texts "The name of the rose" by U. Eco, J. Hayzinga's "Homo ludens", P. Reeker's "Story and Time" (according to I. Bondar-Tereshchenko (Bondar-Tereshchenko, 2003: 59)), "Apocrypha of the Ancient Christians", V. Shukhevych's investigation "The Hutsul land", "Logico-philosophical treatise" by L. Wittgenstein (as noted by T. Prokhasko (Teren, 2020: 274-276; Pidgora-Gvyazdovskiy, 2008).

Without claiming to create a masterpiece in the context of well-known perfect texts, T. Prokhasko points out: “...I allow myself to add my, roughly speaking, notes in the margins of what has already been done and written before me" (Teren, 2020: 225).

In the prose by T. Prokhasko the aesthetics of existence and household hermeneutics have special weight. T. Prokhasko contrasts details and circumstances with the civilization excess and oversaturation. It is attention to the detail, the ability to notice the smallest circumstances, for example, in facial expressions, gestures, intonations that gives T. Prokhasko's prose a special emotional and semantic halo (Kharchuk, 2011: 169). According to the researcher, the source of the mysticism of T. Prokhasko's prose is the mystical philosophy of St. Augustine and Neoplatonism (Ibid.:178).

The writer notes: "I am interested in small manifestations of life. I am interested in details when everything is in something small" (Slavinska, 2011). As the main innovative "trend" of the novel O. Zabuzhko sees the search for an answer to the question of whether it is possible to live in geography contrary to history, at the center of which is a "little man", and whether a 
person can be happy in such conditions (Zabuzhko, 2015: 9). The question of accepting history arises as one that requires an answer to continue the further movement of the culture.

O. Zabuzhko points out that in Prohasko's myth a priority of geography over history (place - over time) is absolute (Ibid.: 11). The writer himself is also aware of this instruction, he is deeply rooted in the family topos, which gives him not only shelter in the course of life, but also ideal conditions for creativity. The house " $<\ldots>$ for most people $<\ldots>$ is the basis of biography and a clear result of existence. And there the memory rests, because it is the easiest for her to cope with the objects" (Prokhasko, 2015: 42). The house as a center of memory and beauty acquires a sacred significance in the novel. "To be accessible, beauty must be able to be worded. And therefore - to be grinded. The house gives that small space in which it is possible to have time to make beauty by own forces" (Ibid.: 43).

Understanding the meaning of an artistic detail, the "small space" of which T. Prokhasko speaks, corresponds to the phenomenological way out of anthropological impasse through the model of self-disclosure of the mind (Vatorpyn, Olkhovykov, 2002: 138).

\section{Methodology}

To implement the tasks of the investigation, the traditional general scientific methods

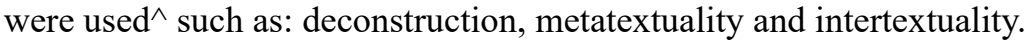

\section{Results and Discussion}

The heroes of the novel "The UnSimple" feel and accept the call of a related topos and adjust their lives according to it: "...saw the place where felt on the spot - related and happy. In a year Francisk returned there and began to build a town" (Prokhasko, 2015: 19). The feeling of accepting a person by a topos is also articulated in the novel (Ibid.: 85). Yalivets's topos also serves as a shelter from external information (Ibid.: 24).

The topos in the novel acquires a sacred meaning, playing the role of a "place of germination": Franz found a place that made travel optional $<\ldots>$ my place will always be at the center of European history, because on these lands history in various forms itself comes to our outdoors" (Ibid.: 37).

Despite his deep personal roots in the topos and perception of the world exclusively through himself, otherwise there is no world - the writer feels as a part of the flow of hundreds of generations and many different processes, both historical and natural, "I am a small fragment in this great stream," he points out (Pleasure to contact, 2015: 199). Among the "surrogates of pastime" that indicate the transition from significant things beyond the sphere of human influence to less significant $\langle\ldots\rangle$, which a person is able to manage, a modern sociologist, researcher of modern society Z. Bauman calls the work on dismantling, reorganization, formation of one's own identity, which requires time and effort (Bauman, 2005: 120).

T. Prohasko arranges his world with the help of fixing historical relics. Referring to his brother Y. Prokhasko (Ukrainian literary critic, essayist, publicist, translator, with whom close friendship is being maintained and who is the most important among the author's authorities), T. Prokhasko notes: "...it seemed that we were the last bearers of certain knowledge, relics and heritage $<\ldots>$ it seemed that if I did not do it, it would all be lost" (Teren, 2020: 93).

Following the biologist K. Lorentz, T. Prohasko identifies the main source of self-identification the image recorded in the first minutes of life, which is the basic or primary landscape: "Thought is constructed from the landscape, which is primary $<\ldots>$. Thinking about something, 
we have to place the thought on a certain surface. We need the known planes. We need the locality" (Prokhasko, 2006: 41).

The landscape that accepted the protagonist and was accepted by the protagonist ("You must truly love places so that they love you" (Prokhasko, 201: 139)) in the author's novel is a means of transcendence of man beyond his borders: " $<\ldots$.. between Petros and Sheshul, Franz thought he was traveling to the heavenly islands. Only a few of the highest peaks peeked over the clouds. The western sun shone only for them $<\ldots>$ Franz ceased to belong to himself, joined some cosmic movements <...>» (Ibid.:37).

Defining the peculiarities of the modern literary process, T. Prohasko points to the lack of good fiction, which would be a comprehension of the past, in general, the historical genre, "about people's lives in the history, as those historical events still live in us $<\ldots>$. We have a lot of problems due to the fact that there is an unspoken past: the UPA veterans, lustrations, former enkavedists, the Ukrainian-Polish conflict, trips to the West and deportations to the East. All this is not comprehended at all" (Prokhasko, 2019).

The protagonist of the novel "The UnSimple" expresses a vision of the role of describing human history as a therapy: "If we knew more human destinies, said Sebastian. This is often the main therapy of the speach" (Prokhasko, 2015: 121). Because "the basis of each private epic is a list of ideas about the places where family history took place ..." (Ibid.: 115), and a huge number of people in the twentieth century contrary to the genetic habit of recording the history of the genus, were forcibly deprived of family memory as a result of repression, resettlement, silence, the desire to preserve the genus, so T. Prokhasko in his novel actually formulates a recipe for survival of the genus and preservation of original identity by means of the affection to the topos.

The writer points out that it is not alternative mythology that is important to him, but the history of the Carpathians, as opposed to the perception of the region as a unique closed land, which stems from the works by Shukhevych, Hnatiuk, Franko, Paul, Soviet ethnography. The author claims that he tried to show in the novel the Carpathians as a territory open to migration (Teren, 2020: 281).

Thus, with the regard to the novel "UnSimple", according to the author, "... the landscape can be the main theme, and the story - the leading idea" (Ibid.: 284).

Genre features of the postmodern pseudo-historical novel are systematized in some works, for example, the study by I. Ashcheulova (Ashcheulova, 2007). Among them there is "the perception of history as an incomplete text, which allows you to create your own version of a historical event or to inscribe an event to a certain era" (Ibid.: 16).

The creation of the text in this case is accompanied by serious work with the sources, the documents of the era. Important works on Western Ukrainian ethnography (for example, N. Hobzey's ethnolinguistic dictionary (Hobzey, 2002), anthologies of fairy tales, legends, etc.) are easy of access to the writer who has a reputation as an intellectual familiar with world literature. The story of Anna and Sebastian's family, "inscribed into a specific historical epoch" (Ashcheulova, 2007: 17), is unfinished, "the plots cannot end", according to T. Prokhasko.

The novel defines the features of the national character (which is actualized in the novel regional Western Ukrainian folk life, and in general the people's regional worldview and type of thinking) with the help of a pseudo-historical plot (Ibid.: 17).

According to T. Gundorova, initiated in the 1980s by Eastern European intellectuals with the idea of "own" Europe, "the project of modernization due to the historical and topographical redistribution of the geopolitical map and romanticization of past history was adopted in the 
1990s by Ukrainian postmodernists" (Hundorova, 2005: 137). The protagonist of the novel by T. Prokhasko creates a kind of geographical utopia: "Sebastian imagined how nice it might have been with that small Carpathia, which he, using the universal chaos, can defend by himself. $\mathrm{He}$ was inventing a beautiful country around Yalivets, where there would be no garbage, everyone would know each other's languages, and the highest institution would be a script bureau, where everyone could submit something really interesting, and the government would be guided by these stories. Everything spoils 'would"' (Prokhasko, 2015: 140).

Despite the important position of the topos in the novel's universe, the minor characters are intended, according to the author, "...to hint to the reader that their place, their utopia can be created anywhere, considering the closeness with those who are close; that utopia is always not so much geographical as interpersonal. What is important for utopia is not the place where everything is going so well, but the right people" (Teren, 2020: 282). Accordingly, the novel gives rise to the idea of the "comparative geography", which connects people with the help of stories about unfamiliar places: "Sebastian said that it was most interesting for him to listen to someone telling stories about places he did not know. $<\ldots>$ Great shifts confuse people, and the basis of speech and way of thinking is the comparative geography" (Prokhasko, 2015: 123).

The strategy of avoiding the linearity of the plot is chosen by T. Prokhasko consciously. The strategy of "text in the text", the method of editing fragments "should show that each $<\ldots>$ hero $\langle\ldots>$ also affects the course of this story", the author points out that the novel is "unfinished, underdone, torn and chaotic", which, in the writer's opinion, turned to be necessary and understandable at the time of writing" (Teren, 2020: 285).

The theme of human rooting in the new geographical landscape as a strategy for the reconstruction of historical discourse sounds quite clear in the novel by T. Prokhasko. There is a parallel with life, as the writer says, as his father's fate in adolescence was transformed by episodes of resettlement to Siberia and return home (Prokhasko, 2016: 64-66). The man has twice gone through a rather painful process of finding roots in a new geographical reality.

Note that the novel by T. Prohasko, according to the author, still retains many unread places, in particular the appearance of Sebastian in Yalivets can be interpreted as a parallel to the quasi-historical novel-saga by A. and S. Golon about adventures in France in the seventeenth century. The description of the novel's "UnSimple" hero's life is reminiscent of the placed into the plot of the saga life story of Vsevolod Golubinov (the real name of S. Golon), husband and co-author of journalist and writer Simona Shangio, known under the pseudonym Anne Golon, who after escape from the revolution of 1917 in Russia was forced to build his own life in France.

There are not only coincidences of events, but also coincidences of the name of Anna with the pseudonym of S. Shangio, a big age difference of the heroes, a sound coincidence of the name Sebastian (from the Greek "sebastos" ("sacred") or from the Latin "Sebastianus" "Sebastian, the one who comes from Sebastia", Sebastia - a city in the historic region of Samaria (Shomron), Israel, or an ancient city in the central part of Asia Minor, modern Sivas) with the colloquial form Seva of the name Vsevolod (by the way, "Seva" is a Sanskrit word meaning "service"), the birth of V. Golubinov in Bukhara in 1903 - the birth of Sebastian in 1893 on Borzhava, stay in Africa during the war and way home through the Black Sea and mountains (Holubinoff, 2005). 


\section{Conclusions}

Thus, most of the mantioned features of the quasi-historical (pseudo-historical) novel are presented in the text by T. Prokhasko, the writer was consciously searching for "a technique that would help to convey the feeling of the timeless, the transnational, the extracontinental" (Teren, 2020: 279), which he brilliantly succeeded in genre coordinates of the quasi-historical novel.

\section{References}

Ashcheulova, Y. (2007). Postmodernystskyi «psevdoystorycheskyi» roman: stratehyy zhanrovoho razvityia [Postmodernist "pseudo-historical" novel: strategies of genre development]. Dergachev readings-2006. Russian literature: national development and regional features: materials of the international scientific conference, Ekaterinburg, October 5-7, 2006. Ekaterinburg: Ural University Publishing House; Publishing House "Union of Writers", 15-24. Retrieved from https://elar.urfu.ru/handle/10995/49566). [In Russian].

Bauman, Z . (2005). Yndyvydualyzyrovannoe obshchestvo [An individualized society]. Moscow: Logos. [In Russian].

Bondar-Tereshchenko, I. (2003). Prosta metaistoriia «NeprOstykh»: pro «beletryzatsiiu mynuloho» v romani T. Prokhaska [A simple metahistory of "The UnSimple": about the "fiction of the past" in the novel by T. Prokhasko]. Word and time. № 6, pp. 58-60. [In Ukrainian].

Epshtein, M. (2000). Postmodern v Rossyy [Postmodern in Russia]. Moscow: R. Elinin's edition. [In Russian].

Hobzey, N. (2002). Hutsulska mifolohiia: etnolinhvistychnyi slovnyk [Hutsul mythology: ethnolinguistic dictionary]. NAS of Ukraine, I. Krypyakevych Institute Of Ukrainian Studies. Lviv. [In Ukrainian].

Hundorova, T. (2005). Pisliachornobylska biblioteka. Ukrainskyi literaturnyi postmodern [Post-Chernobyl Library. Ukrainian literary postmodern]. Kyiv: Krytyka. [In Ukrainian].

Holubinoff, N. (2005). Zhyzn Ann y Serzha Holon, rasskazannaia ykh docheriu Nadei [The life of Anne and Serge Golon, told by their daughter Nadia]. Retrieved from http://www.angelique-world.ru/bio2.html). [In Russian].

Hutcheon, L. (1988). A Poetics of Postmodernism. London, New York.

Kharchuk, R. (2011). Suchasna ukrainska proza. Postmodernyi period [Modern Ukrainian prose. Postmodern period]. Kyiv: VC "Academy". [In Ukrainian].

Kurytsyn, V. (2000). Russkyi lyteraturnyi postmodernyzm [Russian literary postmodernism]. Moscow: OGI. [In Russian].

Lypovetsky, M. (1997). Russkyi postmodernyzm: ocherky ystorycheskoi poetyky [Russian Postmodernism: Essays on Historical Poetics]. Yekaterinburg: Publishing house of the Ural State Pedagogical University. [In Russian].

Pidgora-Gvyazdovskiy, Y. (2008). Taras Prokhasko. PrOstyi [Taras Prokhasko. The Simple]. Retrieved from http://artvertep.com/news/6029_PrOstij.html). [In Ukrainian].

Radist kontaktu. Rozmovy z Tarasom Prokhaskom (2015) [Pleasure to contact. Conversations with Taras Prokhasko]. Brustury: Discoursus. [In Ukrainian].

Prokhasko, T. (2006). Port Frankivsk [Port Frankivsk]. Ivano-Frankivsk: Lileya-NV. [In Ukrainian].

Prokhasko, T. (2016). Donbaska sich [Donbas Sich]. T. Prokhasko. 2015. Lviv: Triada plus. Pp. 64-66. [In Ukrainian]. 
Prokhasko, T. (2015). NeprOsti [The UnSimple]. Ivano-Frankivsk: Lileya-NV. [In Ukrainian]. Skoropanova, I. (2007). Russkaia postmodernystskaia lyteratura [Russian Postmodern Literature]. Moscow: Flinta: Science. [In Russian].

Slavinska, I. (2011). Taras Prokhasko: ukrainska ideia poviazana z lahidnym sydinniam [Taras Prokhasko: the Ukrainian idea is connected with a gentle seating]. Retrieved from https://life. pravda.com.ua/society/2011/01/10/69933/). [In Ukrainian].

Taras Prohasko: Ukrainska literatura ye poky shcho na rivni literatury vnutrishnoho vzhytku [Taras Prokhasko: Ukrainian literature is still at the level of domestic use] (2019). Retrieved from https://rozmova.wordpress.com/2019/09/02/taras-prokhasko-26/). [In Ukrainian].

Teren, T. (2020). Sotvorinnia svitu. Sim dniv iz Tarasom Prokhaskom [Creation of the world. Seven days with Taras Prokhasko]. Kyiv: Pabulum. [In Ukrainian].

Vatorpyn, A., Olkhovykov, K. (2002). Perspektyvy sekuliaryzma y relyhyy v epokhu postmoderna [Prospects for secularism and religion in the postmodern era]. Social sciences and modernity. № 2, pp. 136-145. [In Russian].

Zabuzhko, O. (2015). Z tsoho mozhna zrobyty kilka literatur [Several literatures can be created out of it]. T. Prokhasko. The UnSimple. Ivano-Frankivsk: Lileya-NV. Pp. 8-9. [In Ukrainian]. 